\title{
Res Judicata: The Neglected Defense
}

\author{
David P. Currie $\dagger$
}

In Williams $\dot{v}$. Washington ${ }^{1}$ the state had sued an automobile dealer for violation of its Consumer Protection Act. The dealer argued the statute was unconstitutional; the Washington Supreme Court held to the contrary. The dealer then sued in federal court, ${ }^{2}$ seeking declaratory and injunctive relief on the ground the statute was unconstitutional. Said the Ninth Circuit: Res judicata. ${ }^{3}$

In Grossgold v. Supreme Court the Illinois Supreme Court had suspended an attorney from the practice of law on the basis of his conviction of a crime and had rejected a petition for reconsideration on the basis of a presidential pardon. Thereafter, on the basis of the pardon, the attorney asked a federal court to declare his suspension void and to order him reinstated. Said the Seventh Circuit: Res judicata. ${ }^{5}$

Obvious? But this obvious argument has an uncanny way of eluding both litigants and courts. For example:

(1) Sosna v. Iowa. ${ }^{6} \mathrm{Mrs}$. Sosna sued for divorce in an Iowa state court, which threw her out on the basis of a statutory requirement that divorce plaintiffs reside in the state for one year. Instead of appealing, she sued the state in federal court for declaratory and injunctive relief, arguing that the residence requirement was unconstitutional. In the Supreme Court "both parties urged that we reach the merits," and the Court did: "In this posture of the case . . . we have no occasion to consider whether any consequences adverse to appellant resulted from her first obtaining an adjudication of her claim on the merits in the Iowa state court and only then commencing this action ...."7

$\dagger$ Harry N. Wyatt Professor of Law, The University of Chicago.

I 554 F.2d 369 (9th Cir. 1977).

2 The time sequence is not wholly clear from the opinion. The federal action was filed "[w]hile the state-court case was still before the trial court," 554 F.2d at 370, apparently on remand from the Washington Supreme Court's holding that the statute was valid. Which trial court reached judgment first is not stated.

3 This was an alternative holding; the anti-injunction principle of Younger v. Harris, 401 U.S. 37 (1971), was also invoked. 554 F.2d at 370-71.

+ 557 F.2d 122 (7th Cir. 1977).

5 Again there were alternative grounds: lack of federal jurisdiction and an insufficient case on the merits. 557 F.2d at 124-26.

- 419 U.S. 393 (1975).

Id. at 397 n.3. 
(2) Huffman v. Pursue, Ltd. ${ }^{8}$ At the suit of a local prosecutor, an Ohio court had ordered Pursue's theatre closed for showing obscene movies. Instead of appealing, Pursue filed a federal action attacking the obscenity statute on constitutional grounds, seeking declaratory and injunctive relief. The sole question, said the Supreme Court, was whether interference with the state court proceeding was precluded by the anti-injunction principle of Younger $v$. Harris:" "Appellants did not plead res judicata in the District Court, and it is therefore not available to them here."10

(3) Wooley $v$. Maynard. " Convicted three times for blotting out the state motto on his license plates in violation of a New Hampshire statute, Maynard did not appeal any of the convictions. Rather he filed a federal claim for prospective declaratory and injunctive relief, averring that he intended to obscure the motto of his plates again and arguing that the statute was unconstitutional. The defendants invoked Younger but apparently not res judicata, which the district court considered "a more plausible position for the defendants to take."12 Stating its view that the res judicata defense would also fail, the trial court reached the merits. The Supreme Court affirmed without mentioning res judicata.

(4) Vendo Co. v. Lektro-Vend Corp. ${ }^{13}$ An Illinois trial court had entered a money judgment against Lektro-Vend and others for breach of covenants not to compete. The state supreme court affirmed, holding that the defendants had breached fiduciary obligations owed the plaintiff. Lektro-Vend then obtained a federal injunction against enforcement of the state judgment on the ground that the covenants violated the antitrust laws. On review of the federal injunction in the Supreme Court, res judicata was briefed, but not considered, because the "issue was not presented . . . in the petition for certiorari, and the Court of Appeals did not discuss it."14

These are not isolated cases. All four are taken from the past three terms of the Supreme Court. The same thing happens repeatedly in other courts..$^{15}$ In all these cases the defendants should have

8420 U.S. 592 (1975).

- 401 U.S. 37 (1971). See text and notes at notes $16-34$ infra.

to 420 U.S. at $607-08$ n. 19 ,

" 430 U.S. 705 (1977).

12 Maynard v. Wooley, 406 F. Supp. 1381, 1385 n.6 (D.N.H. 1976).

is 97 S. Ct. 2881 (1977).

is Id. at 2886 n. 4 .

${ }^{15}$ See, e.g., Gipson v. New Jersey Supreme Court, 558 F.2d 701 (3d Cir. 1977) (attorney suspended by state supreme court attacks suspension by action in federal court); Piatt $v$. Louisville \& Jefferson County Bd. of Educ., 556 F.2d 809 (6th Cir. 1977) (after losing state court action attacking vaccination law, pupil files substantially similar complaint in federal 
pleaded, and there is a strong argument that the courts should have found, res judicata.

\section{Alternative Preclusive Theories: Is Res Judicata SUPERFLUOUS?}

A. Younger v. Harris ${ }^{16}$

1. Basis of the Doctrine. This notorious 1971 decision reaffirmed the allegedly long-standing ${ }^{17}$ rule that considerations of equity, comity, and federalism forbid a federal court to enjoin state criminal proceedings, except under "extraordinary circumstances, where the danger of irreparable loss is both great and immediate."18 In Sosna the Court called the parties' attention to Younger, but they chose not to take the bait. ${ }^{19}$ In Wooley the Court held Younger was not a bar. ${ }^{20}$ In Huffman the Court held it was. ${ }^{21}$

The principal vice of the injunction sought in Younger was its disruption of an ongoing state proceeding. In Huffman the state proceedings were apparently over, but the Court thought this immaterial: federal intervention after trial court judgment would "if anything be more highly duplicative, since an entire trial has already taken place"; it would equally disrupt "the State's efforts to protect interests which it deems important"; it would cast "a direct aspersion on the capabilities and good faith of state appellate courts"; and it would deprive the states of the function "of overseeing trial court dispositions of constitutional issues." ${ }^{22}$

While the force of these arguments may be somewhat lessened if the time for a state appeal has expired-a fact the Court in Huffman thought it unnecessary to determine ${ }^{23}$ - the opinion was on firm ground in ruling that "appellee may not avoid the standards of Younger by simply failing to comply with the procedures of perfecting its appeal within the Ohio Judicial system."24 At the most basic level Younger reflects the policy that federal courts should

court). In both cases the court of appeals avoided the merits, without mentioning res judicata, by rather strained applications of the Younger $v$. Harris doctrine.

16401 U.S. 37 (1971).

17 Wechsler, Federal Courts, State Criminal Law and the First Amendment, 49 N.Y.U.

L. Rev. 740 (1974), challenges this historical assertion.

is 401 U.S. at 45 (quoting Fenner v. Boykin, 271 U.S. 240 (1926)).

19 419 U.S. at 396 \& n. 3 .

20430 U.S. at $709-12$.

21 420 U.S. at $605-12$.

$=420$ U.S. at $608-09$.

${ }^{23} \mathrm{Id}$. at $611 \mathrm{n} .22$.

${ }^{24}$ Id. 
"not unduly interfere with the legitimate activities of the States"25 and that the friction incident to federal interference ought not to be tolerated so long as state courts provide an adequate opportunity to resolve federal claims. A litigant who has failed to make full use of his state court opportunity has not made a showing that the opportunity was inadequate. To the extent that Younger represents a federal policy to channel defenses to state prosecutions into state courts, it should not be defeated by a litigant's contrary desire and consequent tactical maneuvers. ${ }^{26}$

2. Limits of the Doctrine. Younger's basic premise, that the opportunity to raise federal issues in defense of a state prosecution is an adequate legal remedy, ${ }^{27}$ is difficult to reconcile with the grant of federal question jurisdiction, ${ }^{28}$ which reflects a congressional judgment that state court remedies for the violation of federal rights are inadequate. As Justice Frankfurter explained:

An "adequate remedy at law," as a bar to equitable relief in the federal courts, refers to a remedy on the law side of federal courts . . . [D]iscretion based solely on the availability of a remedy in the State courts would for all practical purposes repeal the Act of 1875 [conferring federal question jurisdiction]..$^{29}$

25401 U.S. at 44.

${ }^{26}$ See Huffman v. Pursue, Ltd., 420 U.S. at 609: "[W]e do not believe a State's judicial system would be fairly accorded the opportunity to resolve federal issues arising in its courts if a federal district court were permitted to substitute itself for the State's appellate courts." Cf. Gotthilf v. Sills, 375 U.S. 79 (1963) (reading a forfeiture requirement into the mandate of 28 U.S.C. $\$ 1257$ (1970) that the litigant seek review in the highest state court).

${ }^{27} 401$ U.S. at 43-44. See also Steffel v. Thompson, 415 U.S. 452,460 (1974). When the state remedy is found inadequate, Younger is not applied. See, e.g., Gibson v. Berryhill, 411 U.S. 564, 577 (1973) (biased tribunal); Steffel v. Thompson, 415 U.S. 452, 462 (1974) (to invoke state remedy, necessary to violate law).

28 28 U.S.C. $\$ \S 1331,1343$ (1970).

29 Alabama Pub. Serv. Comm'n v. Southern Ry., 341 U.S. 341, 360-61 (1951) (Frankfurter, J., concurring). It may be argued that a federal injunction against pending state proceedings has the same effect as removing them to the federal court, and therefore that such an injunction is inconsistent with Congress's failure to provide for removal on the basis of most federal defenses. See 28 U.S.C. $\$ 1441$ (a) (1970) ("civil action . . . of which the district courts . . . have original jurisdiction"); Louisville \& N.R.R. v. Mottley, 211 U.S. 149, 152 (1908) ("a suit arises under the Constitution and laws of the United States only when the plaintiff's statement of his own claim shows that it is based upon those laws or that Constitution"). But it is not wholly clear that the effect is the same. Removal generally (though not inherently) brings the entire state case into federal court, while pendent jurisdiction in an injunctive action, see Siler v. Louisville \& N.R.R., 213 U.S. 175 (1909), is not likely to be carried so far as to permit the federal court to hold a criminal trial. In any event, while the probable dominance of state law issues is a possible justification for the absence of federal defense removal, I know of no evidence that it was Congress's reason. Since the requirement that the federal question be part of the plaintiff's claim was judicially created, Congress may never have addressed the issue at all. 
Such difficulties aside, ${ }^{30}$ Younger cannot be a complete surrogate for res judicata. No doctrine of forfeiture can bar the suitor who has fully exhausted his state remedies. Moreover, Wooley shows it will not bar one who has failed to appeal a state court judgment either, unless he is effectively attacking that judgment in the federal proceeding. ${ }^{31}$ After forgoing three opportunities to challenge the license plate law in state appellate courts, Maynard was permitted to attack the law's constitutionality in federal court because "the suit is in no way 'designed to annul the results of a state trial' since the relief sought is wholly prospective, to preclude further prosecution." 32

Yes, the Younger doctrine, if one accepts it, can be made to cover the narrow case of a federal plaintiff who attacks a state court judgment he has neglected to appeal. ${ }^{33}$ But there is generally no need to go to the trouble in view of the much more respectable, more straightforward, and broader doctrine of res judicata. ${ }^{34}$

\section{B. Lack of Jurisdiction}

In Rooker $v$. Fidelity Trust $\mathrm{Co}^{35}$ the losing litigant in a state

so I find Younger's conclusion that a state court defense is adequate in a case under 42 U.S.C. $\$ 1983$ (1970) particularly difficult to reconcile with the holding in Mitchum v. Foster, 407 U.S. 225 (1972), that $\$ 1983$ "expressly authorized" injunctions against pending state court proceedings within 28 U.S.C. $\S 2283$ (1970), because $\S 1983$ was based upon the premise that state courts would not adequately protect federal rights. See Redish, The Anti-Injunction Statute Reconsidered, 44 U. CHI. L. REv. 717, 737-38 (1977).

"' But see Roe v. Wade, 410 U.S. 113, 126-27 (1973).

32430 U.S. at 711. Similarly, Younger should have been no help in Sosna, since the plaintiff did not seek to affect the past judgment denying her a divorce.

33 The majority in Huffman suggested that Younger was resorted to only because the obvious plea of res judicata was not made. See 420 U.S. at 594 n.1, 607 n.19 (citing Sosna v. Iowa, 419 U.S. $393,396-97$ n.3 (1975)). More recently, the Court has expressly held that the state's failure to object to a trial court's refusal to invoke Younger made it proper to ignore the issue. Ohio Bureau of Employment Servs. v. Hodory, 431 U.S. 471, 479-80 (1977).

${ }^{34}$ In Lektro-Vend it was argued and rightly held that federal relief was barred by 28 U.S.C. $\$ 2283$ (1970), which forbids injunctions against "proceedings in a state court" with certain exceptions. Those exceptions have, however, been so expanded by "judicial improvisation," contrary to the admonition of Mr. Justice Frankfurter in Amalgamated Clothing Workers v. Richman Bros. Co., 348 U.S. 511, 514 (1955), that $\S 2283$ will often be of no assistance. See, e.g., Mitchum v. Foster, 407 U.S. 225, 242 (1972) (holding $\S 1983$ "expressly authorize[s]" injunctions against state court proceedings by authorizing a "suit in equity" to redress "the deprivation," under color of state law, of federal rights). See generally Redish, The Anti-Injunction Statute Reconsidered, 44 U. CHI. L. Rev. 717 (1977). In Lektro-Vend itself a majority stated in dictum that $\S 2283$ would not bar an injunction against a state court proceeding that was part of a pattern of baseless claims violating the Sherman Act. $97 \mathrm{~S}$. Ct. at 2889 n.6.

In any event, like Younger, $\S 2283$ can be employed only if the federal plaintiff effectively challenges the state court judgment itself.

${ }^{35} 263$ U.S. 413 (1923). 
court action sued in federal court to have the state judgment set aside. The district court dismissed for lack of jurisdiction, and the Supreme Court affirmed: "Under the legislation of Congress, no court of the United States other than this Court could entertain a proceeding to reverse or modify the judgment . . . . To do so would be an exercise of appellate jurisdiction. The jurisdiction possessed by the District Courts is strictly original." ${ }^{36}$

Rooker does not stand alone. Statutes provide that courts of appeals have jurisdiction to review final orders of the Federal Trade Commission ${ }^{37}$ and the National Labor Relations Board..$^{38}$ The courts have not hesitated in concluding that these provisions preclude district court review of both final and nonfinal orders under general jurisdictional provisions. ${ }^{39}$ This principle was generalized in a recent Ninth Circuit case holding a provision for review in the Court of Customs and Patent Appeals ${ }^{40}$ precluded district court review of a decision that a patent belonged to the Atomic Energy Commission: "It is well settled that if Congress, as here, specifically designates a forum for judicial review of administrative action, that forum is exclusive, and this result does not depend upon the use of the word 'exclusive' in the statute."

This argument can be applied to Lektro-Vend and to Huffman, for in both cases success in the federal action would have nullified a state judgment. The general grants of federal question jurisdiction in sections $1331^{42}$ and $1343^{43}$ of Title 28 ought not to be construed to undermine section 1257's clear implication that exclusive jurisdiction to review state court judgments rests with the Supreme Court. ${ }^{44}$

36 Id. at 416.

3715 U.S.C. $\$ 45(\mathrm{c})(1970)$.

38 29 U.S.C. $\$ 160$ (f) (1970).

39 See Sears, Roebuck \& Co. v. NLRB, 433 F.2d 210, 211 (6th Cir. 1970); United Aircraft Corp. v. McCulloch, 365 F.2d 960, 961 (D.C. Cir. 1966); Miles Laboratories, Inc. v. FTC, 140 F.2d 683, 684-85 (D.C. Cir. 1944).

to 42 U.S.C. $\$ 2182(1970)$.

^UMC Indus. Inc. v. Seaborg, 439 F.2d 953, 955 (9th Cir. 1971). See Whitney Nat'l Bank v. Bank of New Orleans, 379 U.S. $411,421-22$ (1965) (citations omitted):

[W] reject the notion that the Board's determination may be collaterally attacked in the District Court by a suit against the Comptroller. Opponents of the opening of a new bank by a bank holding company must first attack the arrangement before the Board, subject only to review by the Court of Appeals . . . That Congress has not expressly provided that the statutory procedure is to be exclusive does not require a different conclusion.

See also Utah Int'l, Inc. v. EPA, 478 F.2d 126 (10th Cir. 1973) (Clean Air Act); Currie, Judicial Review under Federal Pollution Laws, 62 IowA L. REv. 1221, 1231-32, 1247-49 (1977).

428 U.S.C. $\$ 1331$ (1970).

4328 U.S.C. $\$ 1343(1970)$.

428 U.S.C. $\$ 1257$ (1970). 
Moreover, as Rooker observed, to allow district court relief from state court judgments would also undermine section 1257's requirement that an attack upon a state judgment be timely filed. ${ }^{45}$ In Huffman, where no appeal had been taken from the state trial court, it would undermine, in addition, section 1257's requirement that the judgment reviewed be that of "the highest court of a State in which a decision could be had." 46

In form, of course, the federal plaintiffs in Lektro-Vend and Huffman did not seek "review" of state court judgments; they filed original actions that in effect (and in form too in Vendo) would have set those judgments aside. The question therefore is whether the exercise of collateral jurisdiction in a federal trial court is contrary to the purposes ${ }^{47}$ of Congress in providing for Supreme Court review, for as the Court said in Rooker, a litigant "cannot be permitted to do indirectly what he . . . [cannot] do directly." 48 I suspect that the Supreme Court was chosen to review state court judgments because only it had sufficient dignity to make federal review of state courts reasonably palatable; that the highest-state-court requirement was designed to preclude federal interference unless and until state courts had had a full opportunity to avoid that clash; and that the time limits on Supreme Court review were meant to protect parties prevailing in state courts from stale challenges to their judgments. ${ }^{49}$ If any of these surmises is accurate, Rooker is right. ${ }^{50} \mathrm{In}$ -

is 263 U.S. at 416.

1" That this provision embodies a forfeiture for failure to exhaust remedies no longer available is established by Gotthilf v. Sills, 375 U.S. 79 (1963).

${ }^{17}$ Contra, Developments in the Law-Section 1983 and Federalism, 90 Harv. L. Rev. 1133,1334 n.14 (1977), suggesting that a jurisdictional dismissal based on Rooker "would be inappropriate unless it appeared on the face of the complaint that the plaintiff was seeking appellate review of the state court judgment."

4s 263 U.S. at 416.

1 The purpose of statutes limiting the period for appeal is to set a definite point of time when litigation shall be at an end, unless within that time the prescribed application has been made; and if it has not, to advise prospective appellees that they are freed of the appellant's demands.

Mattan S.S. Co. v. Murphy, 319 U.S. 412, 415 (1943).

so Cf. Preiser v. Rodriguez, 411 U.S. 475 (1973), holding the habeas corpus statute provided the sole remedy for attacking unconstitutional state confinement notwithstanding 42 U.S.C. $\$ 1983$ (1970): "It would wholly frustrate explicit congressional intent to hold that the respondents . . . could evade this requirement [exhaustion of state court remedies, 28 U.S.C. $\S 2254(1970)]$ by the simple expedient of putting a different label on their pleadings." 411 U.S. at $489-90$.

It is true that the Rooker analysis has not prevailed in federal habeas corpus, despite the once popular shibboleth that the writ cannot "do service for an appeal." See Brown v. Allen, 344 U.S. 443, 533-48 (1953) (Jackson, J., concurring in result); Sunal v. Large, 332 U.S. 174,178 (1947). The district courts today habitually entertain under the habeas statute, 28 U.S.C. $\$ 2241$ (1970), collateral attacks on convictions that could have been reviewed by the 
deed the conflict with section 1257 policy may well be greater when the federal attack upon the state judgment is labeled an original action rather than a petition for review, for in an original action presumably there will be a new trial, while section 1257 contemplates that review will be limited to the state court record. ${ }^{51}$

The Rooker thesis has two important advantages over res judicata, in cases to which it applies. Section 1738 of Title $28^{52}$ refers the federal court faced with a res judicata defense to the law of the rendering state. But the interests embodied in section 1257's exclusivity are in part federal. Rooker thus provides for a limited, uniform federal law of preclusion in cases that varying state laws may not foreclose. Second, questions of jurisdiction may be raised by the court on its own motion..$^{53}$ The failure of the federal defendant to raise the issue of lack of jurisdiction would not require the court to decide the case, as it does with the affirmative defense of res judicata. ${ }^{54}$ Since to reach the merits of a dispute concluded by a state judgment both wastes federal judicial resources and risks federalstate friction, the matter should not be wholly dependent upon the perspicacity of the defendant's attorney.

The rub is that, like Younger $v$. Harris, the Rooker doctrine is not broad enough to cover cases such as Wooley and Sosna, in which

Supreme Court under $\S 1257$. See, e.g., Brown v. Allen, 344 U.S. 443 (1953). However, since $1948, \S 2254$ (b) of Title 28, in providing that habeas shall not be granted a state convict "unless ... [he] has exhausted the remedies available in the courts of the State," has clearly acknowledged that habeas lies to challenge judgments reviewable in the Supreme Court. There is nothing comparable in the general federal question statutes. Pre-1948 habeas practice was essentially limited to "jurisdictional" matters, see Wainwright v. Sykes, 433 U.S. 72, 79 (1977), that would in any event have justified traditional actions to set aside judgments as void. See RESTATEMENT of JUDGMENTs, §§ 117, 11, 4-8 (1942). Any extensions beyond traditional practice were poorly explained, of questionable correctness under Rooker, and attributable to the existence of a separate jurisdictional provision focused exclusively on personal liberty. Even if, in light of the history of habeas corpus, the statute providing for that writ may fairly be read to express an exception to the general exclusivity of $\S 1257$, to say the same of the general federal question statute would destroy that exclusivity altogether.

The fact that federal courts, even apart from habeas, do entertain actions to set aside judgments for such defects as lack of notice, lack of jurisdiction, or certain types of fraud, e.g., Groves v. Witherspoon, 379 F. Supp. 52 (E.D. Tenn. 1974); Ransome v. Mimms, 320 F. Supp. 1110 (D.S.C. 1971), does not prove that the real problem in Rooker was not one of federal jurisdiction but res judicata. One can readily agree that $\S 1257$ was not meant to outlaw traditional collateral attacks upon void or fraudulent judgments, where direct review is often practically unavailable, without concluding that the important policies of preventing federal-state friction, forestalling stale challenges to state judgments, and providing state courts with opportunity to correct error must in all cases be left to the varying state laws of res judicata.

51 See, e.g., Foster v. Illinois, 332 U.S. 134, 135-36, 138 (1947).

5228 U.S.C. § 1738 (1970).

s3 See Mansfield, C. \& L.M. Ry. v. Swan, 111 U.S. 379, 384 (1884).

st FED. R. Crv. P. 8(c). See Huffman v. Pursue, Ltd., 420 U.S. at 607 n.19. 
the federal plaintiff seeks not to avoid the direct consequences of a state judgment but to relitigate issues that were or should have been raised in the state proceeding. Only res judicata can fill the gap.

\section{RES JUdicata}

\section{A. The Policy Foundation}

The long-established doctrine of res judicata, according to the original Restatement of Judgments, is based upon the "public policy of putting an end to litigation." 55 The draft of the Restatement of Judgments Second suggests reasons for this policy: "fairness to the defendant, and sound judicial administration." 56 In the words of James and Hazard, the policy is to "bring an adjudication to a final conclusion with reasonable promptness and within reasonable limits of cost." 57 To litigate the same matter twice or more would impose costs on the parties and the burdened and subsidized judicial system. Indeed, if a judgment were not conclusive as to what it actually determined, "the adjudicative process would fail to serve its social function" of resolving disputes. ${ }^{58}$ Furthermore, to allow a party to advance arguments in a second proceeding that he could have made in a prior proceeding but did not similarly imposes unnecessary costs on both opposing parties and the judicial system. The question, said the Supreme Court recently in a way that left no doubt as to the answer, "is whether it is any longer tenable to afford a litigant more than one full and fair opportunity for judicial resolution of the same issue." 59

In Sosna, Huffman, Wooley, and Lektro-Vend the federal plaintiffs had a "full and fair opportunity for judicial resolution" of their claims in state court. Res judicata probably should have barred a second round in federal court, as it did in Williams and in Grossgold.

\section{B. Questions of Application}

Perhaps the most obvious case for application of res judicata involves successive actions by the same plaintiff against the same

55 Restatement of Judgments $\$ 1$, Comment a (1942).

st Restatement (Second) of Judgments $\S 48$, Comment a, at 36 (Tent. Draft No. 1 , 1973).

57 F. James \& G. Hazard, Civil Procedure 530 (2d ed. 1977).

ss Id.

5) Blonder-Tongue Laboratories, Inc. v. University of Ill. Foundation, 402 U.S. 313, 328 (1971). For further discussion of the policies underlying res judicata, see A. Vestad, RES Judicata/Preclusion 5-12 (1969). 
defendant in the same court, seeking the same relief on the basis of the same evidence and the same legal arguments. Right or wrong, a judgment in the first such action establishing that the defendant is not liable is a bar to subsequent proceedings..$^{60}$ None of the cases I am considering is this simple. The complicating factors will be discussed one at a time.

1. Second Action in Different Jurisdiction. In all the cases under discussion the first action was in a state court, the second in a federal. But federal respect for state court judgments is not, as is occasionally argued, ${ }^{61}$ a matter of judicial grace. It is the command of Congress in section 1738 of Title 28:

The .. . judicial proceedings of any court of any . . . State, Territory, or Possession . . . shall have the same full faith and credit in every court within the United States and its Territories and Possessions as they have by law or usage in the courts of such State, Territory or Possession from which they are taken. ${ }^{62}$

"Every court within the United States," as one would expect, has been construed to include federal courts. ${ }^{63}$

That two jurisdictions are involved does complicate the federal court's task, for the statute requires only that judgments be given "the same . . . credit . . . as they have . . . in the courts" of the jurisdiction where they are rendered. A court in another jurisdiction therefore has "as much leeway to disregard the judgment ... . as does the State where it was rendered." "Section 1738 thus does not mandate a uniform federal law of res judicata; but it does require that a claim or issue be precluded in federal court if the res judicata law of the state in which the judgment was rendered so indicates.

It is much less clear whether a federal court may hold a claim or issue precluded when it would not be under the law of the rendering state. Although the statutory language ("the same full faith and credit") suggests it may not, the central purpose of the statute seems to be to assure that state judgments are respected elsewhere. To give a judgment greater preclusive effect than it possesses under

so Restatement of Judgments $\S 48$, Comment a, at 191, Illustration 2 (1942).

61 See McCormack, Federalism and Section 1983: Limits on Judicial Enforcement of Constitutional Claims (pt. II), 60 VA. L. REv. 250, 277 (1974).

6228 U.S.C. $\$ 1738$ (1970). That "full faith and credit" to "judicial proceedings" requires that one jurisdiction give res judicata effect to another's judgments has been established "from the beginning." See Magnolia Petroleum Co. v. Hunt, 320 U.S. 430, 438 (1943).

${ }^{63}$ Huron Holding Corp. v. Lincoln Mine Operations Co., 312 U.S. 183, 193 (1941); Davis v. Davis, 305 U.S. 32, 40 (1938).

os Halvey v. Halvey, 330 U.S. 610,615 (1947). 
the law of the rendering state would not offend this policy, and the legitimate interest of the federal forum in reducing its own docket would be served. ${ }^{65}$ On the other hand, this reading of section 1738 might offend state policies limiting the res judicata effect of judgments, and there may be due process problems in giving a judgment greater effect than the court entering it intended, ${ }^{68}$ unless the only consequence is to deny litigants with access to state court the use of a federal forum. To conclude that a federal court may give greater preclusive effect to a state court judgment than the rendering state does would make my case easier; I will assume it may not. ${ }^{87}$

2. Civil Rights Cases. In Huffman, Wooley, and Sosna, the federal plaintiff brought suit under 42 U.S.C. $\$ 1983{ }^{68}$ which provides for private redress of deprivations of federal constitutional or statutory civil rights ${ }^{69}$ caused by persons acting under color of state law. Some commentators have suggested, ${ }^{70}$ and an occasional judge has said, ${ }^{71}$ that section 1983 abrogates or modifies otherwise applica-

${ }^{4}$ See Carrington, Collateral Estoppel and Foreign Judgments, 24 Oню ST. L.J. 381, 383, 387 (1963); Note, Collateral Estoppel in Multistate Litigation, 68 CoLum. L. Rev. 1590, 1592 95 (1968).

"See Vestal, Res Judicata/Preclusion by Judgment: The Law Applied in Federal Courts, 66 Mich. L. Rev. 1723, 1738-39 (1968).

67 Some federal courts have found claims or issues precluded by state judgments without discussing state law. E.g., Blankner v. City of Chicago, 504 F.2d 1037 (7th Cir. 1974), cert. denied, 421 U.S. 948 (1975); Parker v. McKeithen, 488 F.2d 553, 558 n.7 (5th Cir.), cert. denied, 419 U.S. 838 (1974). The court in Parker adverted to the issue, saying there was a "difference of opinion" whether state judgments were to be "accorded force . . . under . . . collateral estoppel . . . or under . . . section 1738" but felt bound to follow "collateral estoppel" (meaning, presumably, federal rather than state law principles of preclusion) by Hyman v. Regenstein, 250 F.2d 502, 510 (5th Cir. 1958), cert. denied, 359 U.S. 913 (1959), which had not discussed the issue. $C f$. Winter v. Lavine, No. 77-7101, slip op. at 6491-6506 (2d Cir. Jan. 16, 1978) (court finds it unnecessary to determine whether the collateral estoppel effect of a prior state suit on a $\S 1983$ federal action should be governed by state or federal law). Restatement (SECOND) of Conflict of Laws $\$ \S 95,96$ (1971), refers all questions of the effect of a judgment to the law of the rendering jurisdiction.

us The language of 42 U.S.C. $\S 1983$ (1970) is:

Every person who, under color of any statute, ordinance, regulation, custom, or usage of any State or Territory, subjects, or causes to be subjected, any citizen of the United States or other person within the jurisdiction thereof to the deprivation of any rights, privileges, or immunities secured by the Constitution and laws, shall be liable to the party injured in an action at law, suit at equity, or other proper proceeding for redress.

- Federal jurisdiction over most $\S 1983$ actions is provided by 28 U.S.C. $\$ 1343$ (3) (1970).

${ }^{70}$ See Averitt, Federal Section 1983 Actions after State Court Judgment, 44 U. CoLo. L. Rev. 191 (1972); McCormack, Federalism and § 1983: Limits on Judicial Enforcement of Constitutional Claims (pt. II), 60 VA. L. REv. 250 (1974); Theis, Res Judicata In Civil Rights Act Cases: An Introduction to the Problem, 70 Nw. U.L. REv. 859 (1976); Developments, supra note 47 , at $1335-43$.

" E.g., Lombard v. Board of Educ., 502 F.2d 631, 635 (2d Cir. 1974), cert. denied, 420 U.S. 976 (1975) (allowing $\S 1983$ action after plaintiff had presented only state law claim in state court); Ney v. California, 439 F.2d 1285, 1288 (9th Cir. 1971) (alternative holding); Brown v. Chastain, 418 F.2d 1012, 1021 (5th Cir. 1969) (Rives, J., dissenting), cert. denied, 
ble principles of res judicata. The premise of section 1983, the argument runs, is that state courts do not provide an adequate opportunity for the vindication of federal rights. To give a state court judgment preclusive effect on subsequent 1983 suits, it is concluded, would undermine the statutory purpose. ${ }^{72}$

No language in section 1983 remotely suggests any modification of res judicata. ${ }^{73}$ The section simply declares the existence of a cause of action. So do many federal statutes, such as the Federal Employers Liability Act; $;^{74}$ nobody doubts that res judicata bars successive state and federal actions under the F.E.L.A. ${ }^{75}$ Indeed if the mere provision of a federal cause of action were sufficient to do away with res judicata, section 1738 would be virtually a dead letter in federal question cases in federal courts, given the paucity of federal common law..$^{76}$

The argument based upon Congress's perception of state court inadequacy would logically destroy section 1738 altogether. All grants of federal jurisdiction are based upon some perceived inadequacy of state courts. Diversity jurisdiction rests upon fear of state court prejudice against "foreigners," 7 federal question jurisdiction upon fear of state court hostility to or misunderstanding of federal rights. ${ }^{78}$ Yet Congress did not carry these policies so far as to oust state courts of concurrent jurisdiction over federal question or diversity cases, nor of cases within section 1983. And section 1738 establishes that when such a case is decided by a state court, its judgment is to be respected. ${ }^{79}$

It is true that mistrust of state courts is at its height when, as

397 U.S. 951 (1970). See also Preiser v. Rodriguez, 411 U.S. 475, 509 n.14 (1973) (Brennan, J., dissenting), saying cases holding res judicata fully applicable "may well be in error."

72 One court has suggested that to apply res judicata to $\$ 1983$ cases would contradict Monroe v. Pape, 365 U.S. 167 (1961). Lombard v. Board of Educ., 502 F.2d 631, 635 (2d Cir. 1974), cert. denied, 420 U.S. 976 (1975). But Monroe held only that a litigant need not exhaust state court remedies before suing under $\S 1983$; it had nothing to say about the effect of a prior state court judgment.

${ }^{73}$ While the entry of a state judgment is action "under color of" state law, the term "deprivation" seems to refer to the action of which complaint is made, not to the mere failure to redress it.

745 U.S.C. $\$ 51$ (1970).

${ }^{75}$ See Lyle v. Bangor \& Aroostook R.R., 237 F.2d 683 (1st Cir. 1956), cert. denied, 353 U.S. 913 (1957).

${ }^{76}$ See Erie R.R. v. Tompkins, 304 U.S. 64 (1938).

7 See id. at 74.

${ }^{78}$ See Martin v. Hunter's Lessee, 14 U.S. (1 Wheat.) 304, 346 (1816).

79 The cases have firmly established that the offensiveness of the foreign judgment to the policy of another jurisdiction is not ground for refusing it full faith and credit. E.g., Magnolia Petroleum Co. v. Hunt, 320 U.S. 430 (1943); Yarborough v. Yarborough, 290 U.S. 202 (1933); Fauntleroy v. Lum, 210 U.S. 230 (1908). This should be plain from the language of the statute. 
in section 1983 cases, a state officer is charged with denying the asserted federal right. It is also possible that the narrower scope of res judicata in 1871 made it unnecessary for Congress to give the question serious attention. Nevertheless, Congress legislated against the background of the requirement of full faith and credit, and it said nothing to suggest an exception was intended for civil rights suits. "Repeals by implication," as the Supreme Court told us just two terms ago, "are not favored." distrust of state courts evinced by section 1983 can be given considerable compass without disturbing section $1738 .^{81}$ It should not be allowed to override the normal rule that Congress intends its statutes to be read together.

The argument that 1983 cases fall outside section $1738^{82}$ draws upon Mitchum $v$. Foster, ${ }^{83}$ in which the Court reasoned from the purpose of the Civil Rights Act of $1871^{84}$ (now section 1983) to the holding that section 1983 "expressly authorized" an injunction against state court proceedings within the meaning of the AntiInjunction Act, section 2283 of Title $28 .{ }^{85}$ "[T] [was] an attempt to remedy the state courts' failure to secure federal rights."86 There was no excuse for the Mitchum decision. Congress in section 2283 made as clear as language permits that federal injunctions against state court proceedings are not to be granted unless some statute says so expressly, and section 1983 says nothing about proceedings in state courts. A Court that would take such liberties with the anti-injunction statute might not hesitate in taking liberties with section 1738 , too, under the impetus of the same policy. But in light of Younger $v$. Harris and its progeny, Mitchum does not prove that the present Court believes section 1983 expresses an overriding policy of state court inadequacy. ${ }^{87} \mathrm{In}$ any event, section 2283 does contain an escape clause for actions

so Radzanower v. Touche, Ross \& Co., 426 U.S. 148, 154 (1976).

${ }^{81}$ Section 1983 in any event provides a federal forum whenever state action other than a judicial judgment is attacked.

22 See, e.g., Averitt, supra note 70, at 210-11.

83 407 U.S. 225 (1972).

"Act of April 20,1871, ch. 22, § 1, 17 Stat. 13 (1871).

${ }^{83} 28$ U.S.C. $\S 2283$ (1970) provides: "A court of the United States may not grant an injunction to stay proceedings in a State court except as expressly authorized by Act of Congress, or where necessary in aid of its jurisdiction, or to protect or effectuate its judgments."

" 407 U.S. at 241.

"77 To deny state judgments res judicata effect in subsequent 1983 cases would undercut Younger: "It would make little sense to require litigants to resort initially to a state forum if that court's judgments could routinely be reopened in the federal courts from which the individual was initially barred." Developments, supra note 47 , at 1336-37. 
under certain statutes; section 1738 does not. The way the Mitchum Court read the "expressly authorized" exception to the antiinjunction statute made it easy to find that section 1983 fell within it; the statute need only "clearly" create a "federal right or remedy, enforceable in a federal court of equity [that] could be given its intended scope only by stay of a state court proceeding." be what section 2283 means, ${ }^{89}$ but there is no language in section 1738 on which to base a similar section 1983 exception.

The fact that section 1738 does not apply in habeas corpus cases has been viewed as support for holding that statute inapplicable to section 1983. But today's habeas statute plainly modifies section 1738 , so it is a poor analogy: "[A state court's] determination after a hearing on the merits of a factual issue . . . shall be presumed to be correct" unless one of eight conditions is met. ${ }^{91}$ Before this language was adopted, however, the Supreme Court in Brown v. Allen ${ }^{92}$ held that claims of jury discrimination and involuntary confession, decided by a state court, could be relitigated on a federal petition for habeas corpus: "The state adjudication ... is not res judicata," ${ }_{93}$ for "else the State court would have the final say which the Congress, by the Act of 1867, provided it should not have."

One may question whether the "Act of 1867 " was really intended to modify section 1738 . While it did say that any state court "proceeding" involving the same subject was "null and void,"95 this language more naturally speaks to pending than to completed proceedings, and the narrow scope of habeas as a means of reviewing convictions in $1867^{96}$ suggests that Congress had no reason to be concerned with undermining res judicata policy. Nevertheless, the statutory reference to state proceedings serves to distinguish section 1983 , which contains no similar provision. Moreover, at the time of Brown the habeas statute provided, as it does today, ${ }^{97}$ that federal

88407 U.S. at 238.

${ }^{80}$ The Mitchum test is critically discussed in Redish, The Anti-Injunction Statute Reconsidered, 44 U. CHI. L. REv. 717, 733-43 (1977).

"See, e.g., McCormack, supra note 70, at 259-62.

128 U.S.C. $\$ 2254$ (d) (1970).

92344 U.S. 443 (1953).

${ }^{23}$ Id. at 458 (Reed, J., for the Court).

" Id. at 500 (separate opinion of Frankfurter, J.).

95 Act of Feb. 5, 1867, ch. 28, § 1, 14 Stat. 385, 386 (1867) (current version at 28 U.S.C. $\S 2254$ (1970)).

9t Habeas had seldom been used before Brown to attack convictions except on grounds, such as lack of jurisdiction or an inadequate opportunity to present objections, that would have avoided res judicata in any event. See Wainwright v. Sykes, 433 U.S. 72, 78-79 (1977); Waley v. Johnston, 316 U.S. 101 (1942); RESTATEMENT OF JudGMENTS §§ 5-6 (1942).

${ }^{97} 28$ U.S.C. \& 2254 (b) (1970). 
relief should not be granted "unless . . . the applicant has exhausted the remedies available in the courts of the State." The implication was clear that federal relief would be available once state remedies were exhausted-in other words, that the state decision would not be res judicata. However inadequate the Court's reasoning, the result in Brown was compelled by the clear incompatibility of section 1738 with the statutory requirement of exhaustion of state court remedies. ${ }^{99}$

The final analogy urged in favor of a section 1983 exception to section 1738 is the Supreme Court's decision in England v. Louisiana State Board of Medical Examiners. ${ }^{100}$ There a federal court had abstained pending state court resolution of a dispute over unclear state law; the Court made clear that the litigants would not be bound against their will by any state court decision on federal issues:

[A]ny conclusion that a litigant who has properly invoked the jurisdiction of a Federal District Court to consider federal constitutional claims can be compelled . . . to accept instead a state court's determination of those claims . . . would be at war with the unqualified terms in which Congress . . . has conferred specific categories of jurisdiction upon the federal courts . . . . ${ }^{101}$

Section 1738, as usual, was not mentioned.

The policy motivating the Court was clear enough: state courts should pass on state issues, federal courts on federal issues. But section 1331 of Title 28 gives federal courts immediate jurisdiction over the whole of a federal question case, ${ }^{102}$ and section 1738 makes state judgments conclusive. The England solution violates both statutes. The federal court declines jurisdiction over part of the case, postpones decision of the rest, and denies full faith and credit to the state court judgment. To reduce the violence abstention does to section 1331, England ignores section 1738.

England's philosophy that the interest in providing a federal forum for federal constitutional claims overrides res judicata policy could be extended to 1983 cases generally. But England arose in a

"8 28 U.S.C. § 2254 (1952).

" Moreover, the Supreme Court without explanation had earlier declared that habeas corpus was a special case with respect to res judicata: "At common law the doctrine of res judicata did not extend to a decision on habeas corpus refusing to discharge the prișoner." Salinger v. Loisel, 265 U.S. 224, 230 (1924).

100375 U.S. 411 (1964).

101 Id. at 415. See McCormack, supra note 70, at 271-73.

${ }^{102}$ See United Mine Workers v. Gibbs, 383 U.S. 715, 725 (1966). 
very special context. The plaintiff had properly invoked federal jurisdiction before there was any state court proceeding, and there was a state court judgment only because the federal court had refused to hear a case within its jurisdiction. ${ }^{103}$ England's abrogation of res judicata followed from the Court's perception that it was the "duty" of a federal court "to take . . . jurisdiction" of the case originally filed; ${ }^{104}$ the whole basis of the decision was that an abstention order should not deprive the plaintiff of his right to a federal forum. ${ }^{105}$ This reasoning is inapposite when there has been no prior refusal to exercise federal jurisdiction properly invoked. Nor can the England analysis support an exception to section 1738 in cases in which federal courts refuse to interfere with state proceedings under the doctrine of Younger $v$. Harris. There is nothing in the Younger cases, as there is in the abstention cases, to suggest that any return to federal court is contemplated. Indeed the basis of Younger is that the state court is an adequate forum for the resolution of the federal claim, and this means, in contrast to England, that the federal court has no duty to exercise jurisdiction at all.

I conclude that section 1738 is applicable to cases under section $1983 .{ }^{106}$

3. Preservation of a Federal Claimant's Choice of Forum. In Huffman, Wooley, and Lektro-Vend the federal plaintiff had been a defendant in state court. It may be consistent with section 1983 policy to hold a litigant who chooses to sue first in state court bound by the state decision; ${ }^{107}$ it is quite another thing, it has been argued, to bind a state court defendant who was dragged against his will into that forum. ${ }^{108}$ For in that case res judicata condemns a federal claim

${ }^{103}$ See 375 U.S. at $413-15$.

104375 U.S. at 415, quoting Willcox v. Consolidated Gas Co., 212 U.S. 19, 40 (1909).

tos See 375 U.S. at $415-16$.

108 Ten courts of appeals have held state court determinations conclusive in subsequent $\S 1983$ cases. Mastracchio v. Ricci, 498 F.2d 1257 (1st Cir. 1974), cert. denied, 420 U.S. 909 (1975); Thistlethwaite v. City of New York, 497 F.2d 339 (2d Cir.), cert. denied, 419 U.S. 1093 (1974); Roy v. Jones, 484 F.2d 96 (3d Cir. 1973); Davis v. Towe, 526 F.2d 588 (4th Cir. 1975), aff'g 379 F. Supp. 536 (E.D. Va. 1974); Brown v. Chastain, 416 F.2d 1012 (5th Cir. 1969), cert. denied, 397 U.S. 951 (1970); Coogan v. Cincinnati Bar Ass'n, 431 F.2d 1209 (6th Cir. 1970); Blanker v. City of Chicago, 504 F.2d 1037 (7th Cir. 1974); Norwood v. Parenteau, 228 F.2d 148 (8th Cir. 1955), cert. denied, 351 U.S. 955 (1956); Francisco Enterprises, Inc. v. Kirby, 482 F.2d 481 (9th Cir. 1973), cert. denied, 415 U.S. 916 (1974); Metros v. United States Dist. Court, 441 F.2d 313 (10th Cir. 1971). The Supreme Court in Preiser v. Rodriguez, 411 U.S. 457 (1973), stated with apparent approval that "res judicata has been held fully applicable to a civil rights action brought under $\$ 1983$." Id. at 497 . No prior state judgment was there at issue.

${ }^{107}$ Of the decisions cited in note 106 supra, in Roy, Davis, Norwood, and Francisco the federal plaintiff had been a plaintiff in state court.

${ }^{103}$ See commentary cited in note 70 supra. One writer seems to suggest that the same 
to the mercies of a tribunal Congress in section 1983 found inadequate.

The answer is essentially the same as to the contention that res judicata never applies in section 1983 cases: nothing in the statutory language suggests Congress meant to push its policy to the point of amending section 1738. In cases involving successive litigation in two states, full faith and credit generally operates to bind defendants as well as plaintiffs, ${ }^{109}$ though they had no choice of forum. Supreme Court review, not collateral attack, is the avenue of relief from errors of federal law. The normal means of effectuating a congressional judgment that state courts afford inadequate protection of federal defenses would have been to authorize removal by state court defendants raising those defenses. Younger reinforces the natural inference that Congress in failing to provide in section 1983 for such removal ${ }^{110}$ meant to allow state courts to resolve federal defenses." If Congress wants to provide a federal claimant the extraordinary option of relitigating issues pertinent to state court litigation, it may say so, as it has in habeas corpus. ${ }^{112}$ An exception to section 1738 should not be inferred from the general legislative distrust of state courts evidenced by 1983 , and most courts have not done so. ${ }^{113}$

4. Different Parties. In Sosna the state court suit was a divorce action by Mrs. Sosna against her husband. Her subsequent federal action was against the state and one of its officers. Had she won in the state court, her victory would not have bound the federal defendants, since they were not parties to the first action. ${ }^{114}$ Once upon a time the rule of "mutuality" would have barred them from taking advantage of a decision against Mrs. Sosna as well. ${ }^{115}$

The California Supreme Court abandoned the mutuality requirement in a perceptive 1942 opinion by Mr. Justice Traynor:

The requirements of due process of law forbid the assertion of a plea of res judicata against a party unless he was . . . a party

analysis be used to avoid res judicata in cases in which a plaintiff is forced into state court by fear that a federal court might abstain. McCormack, supra note 70, at 273-75, 293.

100 E.g., Durfee v. Duke, 375 U.S. 106 (1963); Fauntleroy v. Lum, 210 U.S. 230 (1908).

110 See 28 U.S.C. \$ 1441(a) (1970).

'I' See generally Comment, Federal Court Stays and Dismissal in Deference to Parallel State Court Proceedings: The Impact of Colorado River, 44 U. CH. L. REv. 641, 666-71 (1977).

11228 U.S.C. $\$ 2254$ (1970). See also 42 U.S.C. § $2000 \mathrm{e}-5$ (1970) (fair employment provisions of the 1964 Civil Rights Act).

${ }^{113}$ Res judicata barred state defendants from suing under $\S 1983$ in the Mastracchio,

Thistlethwaite, Brown, Coogan, Blankner, and Metros cases cited in note 106 supra.

i" See Restatement of Judgments § 93 (1942).

115 See id. 
thereto or in privity with a party thereto . . . . There is no compelling reason, however, for requiring that the party asserting the plea of res judicata must have been a party, or in privity with a party, to the earlier litigation. ${ }^{116}$

The United States Supreme Court, noting a general trend away from the mutuality rule, agrees. ${ }^{117}$ So does the draft of the new Restatement of Judgments. ${ }^{118}$ The decisive consideration, as Judge Hastie said in a passage quoted approvingly by the Supreme Court, is that "a party who has had one fair and full opportunity to prove a claim and has failed in that effort, should not be permitted to go to trial on the merits of that claim a second time." 119 It should therefore be irrelevant that the parties who would have benefited from res judicata in Sosna were not parties to the state court action.

5. Criminal Judgments. The state court judgments in Wooley v. Maynard were criminal convictions, and the "traditional" view, said to represent "the preponderance of authority" as recently as $1969,{ }^{120}$ is that criminal convictions are not entitled to res judicata effect in later civil actions.

The only reasons commonly given for this position are quite unpersuasive. That the parties may not be identical ${ }^{121}$ is the discredited mutuality argument discussed above. It has no greater force in this context, and it has no application to Wooley, where the state or its officer was a party to all cases. The second reason is based on the difference in burden of proof between criminal and civil cases. ${ }^{122}$ But while the demanding beyond a reasonable doubt standard of proof in criminal cases means that an acquittal generally does not establish the absence of civil liability, ${ }^{123}$ which is governed by a preponderance of the evidence standard, the disparate burdens of proof cannot justify a court sitting in a civil action in declining to

118 Bernhard v. Bank of America Nat'l Trust \& Sav. Ass'n, 19 Cal.2d 807, 812, 122 P.2d 892, 894 (1942) (emphasis added).

117 Blonder-Tongue Laboratories v. University of $\mathrm{Ill}$. Foundation, 402 U.S. 313 (1971). Though the Court purported to limit its decision to the patent context before it, there is no reason to doubt the Court will follow the same rule elsewhere.

118 Restatement (SEcond) of Judgments, $\$ 88$ (Tent. Draft No. 2, 1975).

11 Bruszewski v. United States, 181 F.2d 419, 421 (3d Cir.), cert. denied, 340 U.S. 865 (1950) (quoted in Blonder-Tongue Laboratories, Inc. v. University of Tll. Foundation, 402 U.S. 313, 324 (1971)).

:20 See A. Vestal, supra note 59, at 373.

121 See, e.g., Moore v. Young, 260 N.C. 654, 657, 133 S.E.2d 510, 513 (1963); 2 A. FreEMAN, JUDGMENTS $\S 654$ (5th ed. 1925).

122 See 2 A. FreEman, supra note 121 , at $\$ 654$.

123 See Tennessee Odin Ins. Co. v. Dickey, 190 Tenn. 96, 99, 228 S.W.2d 73, 74 (1950); State v. Benavidez, 365 S.W.2d 638, 640 (Tex. 1963); A. VESTAL, supra note 59, at 369. 
give a prior criminal conviction res judicata effect. ${ }^{124}$ As Professor Vestal convincingly argues, so long as "the convicted party has had every opportunity and incentive to litigate the issue of his guilt," 125 the traditional rule should not be followed. The Supreme Court has noted with evident favor a general trend toward acceptance of this view. ${ }^{126}$ The Court has itself given a federal conviction res judicata effect in a later civil action by the United States, ${ }^{127}$ and in another context it has abandoned the mutuality rule. ${ }^{128}$ Lower federal courts have, without much discussion of this problem, given res judicata effect to prior criminal convictions in section 1983 cases. ${ }^{129}$ Several state courts in well-reasoned opinions have adopted the Vestal position without regard to whether the party asserting res judicata was a party to the prior criminal action, ${ }^{130}$ and other courts should follow suit.

Some states that generally apply res judicata to criminal convictions make an exception for "relatively minor matters such as traffic violations." 131 In Oregon this result is prescribed by statute, ${ }^{132}$ in Pennsylvania by judicial decision. ${ }^{133}$ The rationale for this exception, according to the Pennsylvania court, is to prevent a defendant from suffering disproportionate and unforseen consequences for making an inadequate defense to a minor charge: in such a case it is not clear the defendant has "taken advantage of his day in court," and it would be unreasonable to bind him as to a civil liability

i24 See, e.g., Eagle Star \& British Dominions Ins. Co. v. Heller, 149 Va. 82, 88-89, 140 S.E. 314,323 (1927); A. FrEEMAN, supra note 121, at $\S \S 656-57$.

125 A. VestaL, supra note 59 , at 382.

126 Blonder-Tongue Laboratories, Inc. v. University of Ill. Foundation, 402 U.S. 313, 327 (1971).

12 Local 167, Int'l Bhd. of Teamsters v. United States, 291 U.S. 293, 298 (1934).

128 See text and notes at notes 113-19 supra.

123 See, e.g., the Mastracchio, Thistlethwaite, and Metros decisions cited in note 106 supra. See also Williams v. Liberty, 461 F.2d 325 (7th Cir. 1972), and Kauffman v. Moss, 420 F.2d 1270 (3d Cir.), cert. denied, 400 U.S. 846 (1970), both recognizing the applicability of res judicata to state criminal judgments in $\S 1983$ cases but holding that the issues at stake had not been decided in state court.

${ }_{130}$ E.g., Teitlebaum Furs, Inc. v. Dominion Ins. Co., 58 Cal. 2d 601, 606-07, 375 P.2d 439, 441-42, 25 Cal. Rptr. 559, 561-62 (1962); Casey v. Northwestern Security Ins. Co., 260 Or. 485, 491, 491 P.2d 208, 210-11 (1971); Hurtt v. Stirone, 416 Pa. 493, 498-99, 206 A.2d 624, 628 (1965). Other decisions have adopted an exception to the traditional anti-preclusion rule in cases in which a convicted criminal seeks to benefit from his own wrong, as when as arsonist sues to collect on fire insurance. Compare, e.g., Eagle Star \& British Dominions Ins. Co. v. Heller, 149 Va. 82, 140 S.E. 314 (1927), with Smith v. New Dixie Lines, Inc., 201 Va. 466, 111 S.E.2d 434 (1959).

131 See Hurtt v. Stirone, 416 Pa. 463, 499, 206 A.2d 624, 627 (1965) (dictum).

1321975 Or. Laws ch. 542, $\$ 1$, (codified at OR. REv. STAT. ch. 41.905 (1977)), overruling Meyers v. Burwell, 271 Or. 84, 530 P.2d 833 (1975). See Reinsch v. Quines, 275 Or. 97, 546 P.2d 135 (1976).

${ }^{133}$ Loughner v. Schmelzer, $421 \mathrm{~Pa} .283,218$ A.2d 768 (1966). 
"probably not within contemplation at the time of the conviction." 134 These considerations have substantial force when a milliondollar personal injury judgment is based on a speeding conviction. They have very little in Wooley, where the issue foreclosed to the state defendant by the first conviction for obscuring the state motto on his license plates is his right to carry on identical conduct in the future-a consequence neither disproportionate nor difficult to foresee. ${ }^{135}$

6. Issues Not Litigated. In Huffman and Sosna the opinions do not reveal whether the state courts were asked to hold the challenged statutes unconstitutional. In Lektro-Vend the Sherman Act defense, originally presented in state court, was withdrawn before final decision. ${ }^{138}$ In Wooley the defendant "proceeded to explain [to the state court] his religious objections to the motto,"137 but did not litigate the constitutional question there. ${ }^{138}$ The district court in

${ }^{134}$ Hurtt v. Stirone, $416 \mathrm{~Pa}$. at 499,206 A.2d at 627.

135 This is another dimension to the problem of the res judicata effect of criminal judgments. An ancient taboo was said to prevent one jurisdiction from enforcing the "penal" laws of another, and the Supreme Court once assumed, long ago, that this prohibition extended to the recognition of "penal" judgments under the predecessor to $\$ 1738$. Huntington v. Attrill, 146 U.S. 657 (1892). The Court did not so hold, however, since it held the law in question not "penal." The basis for the "penal" exception has always been shaky. Judge Learned Hand explained that it would be unseemly if laws so central to one state's operation were subjected to scrutiny to determine their compatibility with another's public policy, Moore v. Mitchell, 30 F.2d 600, 604 (2d Cir. 1924) (concurring opinion), aff'd on other grounds, 281 U.S. 18 (1930), but the insult seems far greater if the second jurisdiction refuses to enforce the other's law altogether as a matter of course. Moreover, local public policy is no excuse under the cases for refusing to respect state court judgments. See cases cited in note 79 supra.

The flimsy arguments against enforcing foreign penal claims are flimsier still once those claims are reduced to judgment. The Supreme Court's square holding that one state must enforce another's judgment for taxes despite their long-standing assimilation to penal claims strongly suggests that criminal judgments are not outside the broad reference to "judicial proceedings" in $\S 1738$ :

We can perceive no greater possibility of embarrassment in litigating the validity of a judgment for taxes and enforcing it than in any other for the payment of money . . . . In the circumstances here disclosed no state can be said to have a legitimate policy against payment of its neighbor's taxes, the obligation of which has been judicially established.

Milwaukee County v. M.E. White Co., 296 U.S. 268, $276-77$ (1935). Similarly, whatever might be the case were a federal court asked to try violators of New Hampshire's license plate law (even this is expressly authorized when the defendant is a federal officer or cannot enforce certain federal rights in state court, 28 U.S.C. $\$ \S 1442,1443(1970)$ ), the fact that the state proceedings in Wooley were criminal affords no reason to believe it would be embarrassing or otherwise inappropriate to accord those proceedings preclusive effect as to the constitutionality of that law. None of the courts asked to give preclusive effect to state criminal judgments, see cases cited in note 129 supra, has been troubled by this problem.

$13897 \mathrm{~S}$. Ct. at 2885.

${ }^{137} 430$ U.S. at 708.

139 Maynard v. Wooley, 406 F. Supp. 1381, 1385 n.6 (D.N.H. 1976). 
Wooley thought this fatal to any res judicata defense: "The first circuit has held that a state criminal conviction will have a preclusive effect in a federal civil rights action only with respect to matters actually litigated and decided at the state criminal trial." 139

The strength of the policy underlying res judicata is greatest when an issue has actually been litigated and decided; only then is there the double expenditure of actual relitigation. But the res judicata principle is not so limited. Even under the first Restatement of Judgments, the plaintiff who lost a lawsuit was not permitted to try again on the basis of new evidence ${ }^{140}$ or a different legal theory, ${ }^{141}$ nor could a losing defendant try again on the basis of a defense he had failed to interpose the first time around:142 "Where . . . the second action is based upon the same cause of action as that upon which the first action was based, the judgment is conclusive as to all matters which were litigated or might have been litigated in the first action." ${ }^{143}$ James and Hazard have concisely stated the reason: "Wherever there will be a large overlap of issues or evidence if two trials are held, it is wasteful to society and harassing to the adversary to have more than one . . ."."144

Forfeiture of legal rights for failure to assert them at the appropriate time is no novel phenomenon. It is the very foundation of statutes of limitations and of time limits on the filing of appeals. ${ }^{145}$ The Supreme Court has upheld a court's refusal to consider contentions that were never presented to the appropriate administrative agency. ${ }^{146}$ Even in habeas corpus, where the overwhelming interest in remedying unlawful restrictions on personal liberty might be thought to outweigh ordinary considerations of judicial efficiency, ${ }^{147}$ the Court has recently returned to the view that a failure to assert a constitutional objection within the time prescribed by state law

139 Id.

110 REstatement of Judgments $\$ 48$, Illustration 1 (1942).

is Id. $\$ 63$ \& ch. 3, Introductory Note at 158.

112 Id. ch. 3, Introductory Note at 158-59.

"s Id. at 159 (emphasis added).

"' F. JAMES \& G. HAZARD, supra note 57, at 542-43. See also Restatement (SEcond) of JudGMENTs $\$ 48$ Comment a, at 36 (Tent. Draft No. 1, 1973):

[F]airness to the defendant, and sound judicial administration, require that at some point litigation over the particular controversy come to an end ... even though the substantive issues have not been tried, especially if the plaintiff has failed to avail himself of opportunities to pursue his remedies in the first proceeding . . . .

14s E.g., FED. R. ApP. P. 4 (30 days for filing notice of appeal from most civil judgments of U.S. district courts).

"16 McGee v. United States, 402 U.S. 479 (1971).

${ }^{\prime}$ See Fay v. Noia, 372 U.S. 391 (1963). 
precludes raising it in federal court. ${ }^{148}$ Res judicata policy demands no less.

Professor Edward Cleary has argued that forfeiture of a right is a disproportionate penalty for what is often an inadvertent procedural default: if the result of the omission is added litigation costs, the remedy should be an order to bear the costs of the second proceeding. ${ }^{149}$ Louisell and Hazard suggest the contrary arguments: the public suffers too from relitigation since court fees do not cover the cost of providing courts; and leaving matters that should have already been adjudicated unsettled imposes "human and social costs" of uncertainty that cannot effectively be recompensed. ${ }^{150}$ Furthermore, the cost of tailoring the remedy to the harm done may be too great-at some point efficiency demands an end to litigation. In any event, Cleary's position amounts to an attack on a long-settled and fundamental principle of res judicata. It is not likely to be generally accepted in the foreseeable future.

Several federal courts have applied res judicata in section 1983 actions to bar claims that were not but could have been decided in prior state litigation. ${ }^{151}$ The Second Circuit's contrary argument that section 1983 policy requires that a state court litigant be permitted to split his federal and state issues ${ }^{152}$ is no more persuasive than the broader section 1983 arguments discussed above, and for the same reasons.

The federal plaintiffs in Sosna, Huffman, Wooley, and LektroVend all had the opportunity to litigate their federal claims in prior state court proceedings. They chose instead to file separate actions in federal court, thereby imposing unnecessary costs upon opposing parties and the judicial system, contrary to the policy underlying res judicata. ${ }^{153}$ Their choice not to take advantage of their opportunities should not have avoided application of res judicata.

7. Different Causes of Action? In Lektro-Vend and in

48 Wainwright v. Sykes, 433 U.S. 72, 87-91 (1977) (failure to object at trial to use of confession allegedly obtained in violation of defendant's Miranda rights).

1s Cleary, Res Judicata Reexamined, 57 YAl. L.J. 339, 350 (1948).

130 D. Louisell \& G. Hazard, Cases and Materials on Pleading and Procedure 622 (3d ed. 1973).

151 E.g., Blankner v. City of Chicago, 504 F.2d 1037, 1041, 1042 (7th Cir. 1974); Francisco Enterprises, Inc. v. Kirby, 482 F.2d 481, 485 n.5 (9th Cir. 1973); Flynn v. State Bd. of Chiropractic Examiners, 418 F.2d 668, 668 (9th Cir. 1969); Frazier v. East Baton Rouge Parish School Bd., 363 F.2d 861, 862 (5th Cir. 1966).

${ }_{152}$ Lombard v. Board of Educ., 502 F.2d 631, 635-37 (2d Cir. 1974).

${ }^{153}$ Moreover, to encourage state defendants to reserve federal issues for separate federal actions would offend the policy of federalism underlying Younger v. Harris. For present purposes, however, this is immaterial, since $\$ 1738$ ties the res judicata effect of state judgments to state law, and since I am assuming no stricter federal rule can be applied. 
Huffman, state court defendants sought federal relief that would have completely negated the force of the judgments entered against them. In the former the judgment was attacked by name, while in the latter the federal court was asked to open a theatre the state court had ordered closed. This was also true in all of the decisions I have found in which federal courts have held res judicata a bar to section 1983 claims not actually litigated in state court. ${ }^{154}$ In Sosna and in Wooley, however, the federal plaintiffs did not seek to obtain the divorce already denied or to upset the convictions already entered. The question therefore arises whether the federal and state proceedings in Sosna and Wooley were on different "claims" or "causes of action" for res judicata purposes, for in such circumstances the doctrine traditionally has had narrower application: ${ }^{155}$

[T] hat a judgment estops not only as to every ground of recovery or defense actually presented in the action, but also as to every ground which might have been presented, is strictly accurate, when applied to the demand or claim in controversy .... But where the second action between the same parties is upon a different claim or demand, the judgment in the prior action operates as an estoppel only as to those matters in issue or points controverted, upon the determination of which the finding or verdict was rendered. ${ }^{156}$

This distinction is recognized in the Restatement of Judgments ${ }^{157}$ and in the draft of its revision. ${ }^{158}$ It seems to be the basis of the First Circuit's dictum, ${ }^{159}$ followed by the trial court in Wooley, ${ }^{160}$ that state criminal judgments are conclusive in section 1983 actions only as to matters actually decided. It is approved by James and Hazard, who generally favor a considerable degree of preclusion. ${ }^{161}$

As a sheer matter of federal precedent, the federal plaintiffs in both Wooley and Sosna presented new causes of action. Elderly Supreme Court decisions found separate causes for res judicata pur-

154 See cases cited note 106 supra.

Iss See Sea-Land Servs. v. Gaudet, 414 U.S. 573, 578-79 (1974).

${ }^{156}$ Cromwell v. County of Sac, 94 U.S. 351, 353 (1876). There are three conventional prerequisites to issue preclusion. The issue in the first action must have been litigated, determined by the court, and that determination must have been necessary to support the judgment. F. JAMES \& G. HAZARD, supra note 57, at 563-71.

157 RESTATEMENT OF JUDGMENTS § 68 (1942).

158 Restatement (Second) of Judgments \$ 68, Comment e (Tent. Draft No. 1, 1973).

${ }^{50}$ Mastracchio v. Ricci, 498 F.2d 1257, 1260 (1st Cir. 1974). See also Williams v. Liberty, 461 F.2d 325 (7th Cir. 1972); Kauffman v. Moss, 420 F.2d 1270 (3d Cir.), cert. denied, 400 U.S. $846(1970)$.

iso Maynard v. Wooley, 406 F. Supp. 1381, 1385 n.6 (D.N.H. 1976).

11 F. JAMES \& G. HAZARD, supra note 57, at 564-65. 
poses in actions on different coupons from the same bonds; ${ }^{162}$ for successive installments due under a pension statute; ${ }^{163}$ for duties on successive imports of identical wool; ${ }^{184}$ and for taxes on the income from identical contracts. ${ }^{165}$ However, the director of the American Law Institute has noted a general tendency in the courts "to be progressively more critical of needless repetition in resorting to judicial processes." 160 The Supreme Court, making the same observation in support of its rejection of the mutuality rule, has pointed out that

the abrogation of mutuality has been accompanied by other developments - such as expansion of the definition of "claim" in bar and merger contexts and expansion of the preclusive effects afforded criminal judgments in civil litigation-which enhance the capabilities of the courts to deal with some issues swiftly but fairly. ${ }^{107}$

Accordingly, under the revised Restatement of Judgments a single "claim" (cause of action) for res judicata purposes "includes all rights of the plaintiff to remedies against the defendant with respect to all or any part of the transaction, or series of connected transactions, out of which the action arose." 168 Under this test one cannot in separate actions litigate the simultaneous invasion of two distinct rights, as when person and property are damaged in the same collision. ${ }^{169}$ And a series of substantially similar acts may be treated as a single claim: "[F]airness to the defendant as well as the public convenience may require that they be dealt with in the same action." 170 The familiar federal compulsory counterclaim rule expresses a similar philosophy-res judicata policy requires a defendant to assert a counterclaim arising out of the "same transaction or occurrence" as the plaintiff's claim against him, or be forever barred from suing on it.171 "The law of res judicata," says the commentary to the new Restatement, "now reflects the expectation that parties who are given the capacity to present their 'entire controver-

162 Cromwell v. County of Sac, 94 U.S. 351 (1877).

163 United States v. Moser, 266 U.S. 236 (1924).

wi United States v. Stone \& Downer Co., 274 U.S. 225 (1927).

tes Commissioner v. Sunnen, 333 U.S. 591 (1948). See note 189 infra.

ibs Restatement (SEcond) of Judgments Foreword, at vii (Tent. Draft No. 1, 1973).

167 Blonder-Tongue Laboratories, Inc. v. University of I1l. Foundation, 402 U.S. 313, 327

(1971) (footnotes omitted).

188 Restatement (Second) of Judgments $\$ 61$ (1) (Tent. Draft No. 1, 1973).

${ }^{168}$ Id. $\$ 61$, Comments a \& b, Illustrations $1 \& 2$.

${ }^{170} I d$., at Comment $\mathrm{d}$.

in Fed. R. Crv. P. 13(a). 
sies' shall in fact do so." 172 Under this modern view successive divorce petitions and successive violations of the license plate law might plausibly be considered single causes of action.

The decision whether to apply res judicata to issues not actually litigated should be made in light of the policies underlying that doctrine ${ }^{173}$ - the competing interests "of the defendant and of the courts in bringing litigation to a close" and "of the plaintiff in the vindication of a just claim." 174 More specifically, the reason res judicata is given narrower scope when the second proceeding is on a different cause of action is that otherwise a litigant might suffer unforeseeable effects on unrelated claims. Not only would this result be unfair, it might not serve the aim of judicial economy. The risk of being bound in a later, unrelated, law suit to an adverse finding on an issue not litigated in a prior suit might induce parties to litigate all possible issues to the utmost in the initial proceeding. ${ }^{175}$

These concerns are legitimate but they have no applicability to the cases under consideration. In Huffman the ultimate practical question was the same in both state and federal actions-whether the theatre could be operated in the future. In Lektro-Vend the federal antitrust claim related to the same conduct that was the subject of the state suit. In Sosna and in Wooley the federal action dealt with future instances of conduct identical to the conduct whose legality had been litigated in state court. It could scarcely have been unforeseeable-least of all by Sosna and Maynard themselves-that the former might try again to get divorced or the latter to obscure his license plate, and that if they did the state litigation might affect their later actions. A favorable ruling on the alleged unconstitutionality of state laws respecting dirty movies, residency requirements for divorce, and license plate mottos would have secured victory in state court for the federal plaintiffs in Huffman, Sosna, and Wooley. A favorable decision on the antitrust defense would have done the same in Lektro-Vend. In each case there was adequate incentive and, so far as appears, adequate opportunity to raise the federal question. Res judicata policy is offended by permitting a separate, expensive federal action.

The desired result could be reached by redefining "cause of action" to reflect modern notions of the underlying policies, at the

172 Restatement (Second) of Judgments $\$ 61$, Comment a at $80-81$ (Tent. Draft No. 1 , 1973).

173 See F. JAMES \& G. HAZARD, supra note 57, at 544.

${ }^{174}$ Restatement (Second) of Judgments $\$ 61$, Comment b, at 81 (Tent. Draft No. 1, 1973).

175 F. JAMEs \& G. HAZARD, supra note 57, at 564-65. 
expense of Supreme Court precedents. It could also be achieved, at the expense of a firmly established black-letter rule, by avoiding the unnecessary "cause of action" terminology altogether. Perhaps the time has come to abandon the unhelpful distinction between res judicata and "collateral estoppel" and to ask simply whether the party to be precluded had adequate opportunity to litigate the matter in the earlier proceeding and whether the matter is closely enough related to the original controversy ${ }^{176}$ so that judicial economy would be served by confining litigation to one proceeding. ${ }^{177}$ If these two conditions are satisfied, issue preclusion will generally be neither unforeseeable nor unfair. The revised Restatement suggests the way. While purporting to adhere to the traditional formulation that collateral estoppel extends only to matters actually litigated, ${ }^{178}$ the commentary defines the "issue" litigated broadly enough" preclude bringing forth new evidence or new legal theories to support contentions made in the first proceeding. ${ }^{180}$ Thus the current Restatement view is that res judicata does sometimes forbid litigation, even in a suit on a different "claim," of some matters not actually decided before. This reasoning justifies forbidding further litigation in Sosna, Huffman, Wooley, and Vendo.

7. Questions of Law. There has been some uncertainty regarding the extent to which res judicata effect is to be given to determinations of "questions of law." The original Restatement took the position that such a determination was not conclusive in a subsequent proceeding "on a different cause of action, except where both causes of action arose out of the same subject matter or transaction," and not even then "if injustice would result."181

"Question of law" is an elusive concept. Obviously the term embraces questions that can be answered by general statements as to the content of the law, such as that damage negligently caused is compensable. It is also true in a sense that the decision that a particular defendant negligently injured a particular plaintiff an-

176 This is not to suggest a new categorical test for issue preclusion, but to mention the major considerations in a functional approach to the problem.

17 Cf. United Mine Workers v. Gibbs, 383 U.S. 715, 725 (1966) (a single constitutional "case," for purposes of determining a federal court's power to adjudicate a state claim as pendent to a federal claim, exists when the claims "derive from a common nucleus of operative fact").

${ }_{178}$ Restatement (Second) of Judgments $\$ 68$, Comment e (Tent. Draft No. 1, 1973).

172 Professor Polasky noted that the scope of collateral estoppel depends upon how broadly the "issue" decided is defined. See Polasky, Collateral Estoppel-Effects of Prior Litigation, 39 Iowa L. Rev. 217, 222-24 (1954).

180 Restatement (Second) of Judgments, Comments d \& e (Tent. Draft No. 1, 1973).

181 Restatement of Judgments $\$ 70$ (1942). 
swers a "question of law" in that it states a legal conclusion, ${ }^{182}$ though the issue is generally left to a jury, whose function is to determine the "facts." 183

There is no reason why all "questions of law," broadly defined, should be outside the normal rules of res judicata. Several of the original Restatement's examples of "questions of law"-such as the "legal sufficiency" of a particular contract, whether the employment of a plaintiff seeking a pension was "of a type included within the statute," or whether the issuance of a note was ultra vires ${ }^{184}$ - seem to be at the very heart of collateral estoppel. In fact the Restatement commentary expressly states that res judicata does not apply to the determination of "merely evidentiary facts," but only to the ultimate facts in issue. ${ }^{185}$ Those ultimate facts, so far as I can determine, are the same matters the Restatement elsewhere . characterizes as matters of "law."

It would be undesirable to hold a party forever bound by a very general statement of the law, such as that "commercial" speech is never protected by the first amendment, since such a holding might have enormous consequences on wholly unrelated activities not foreseeable at the time of the first litigation. But nothing of the sort need be done to justify preclusion in the four cases under consideration. My argument is only that the first litigation finally determined, in Lektro-Vend, that the conduct there in issue did not violate the antitrust laws; in Huffman, that the movies there in issue were such as to justify closing the theatre; in Sosna, that the plaintiff could not obtain a divorce until she had lived a year in Iowa; in Wooley, that the defendant had no constitutional right to obscure the motto on his license plates. In none of these cases could the conduct that was the basis of the subsequent federal action be fairly characterized as unforeseeable, nor could the potential relevance to the federal action of the prior state court proceeding.

Even the first Restatement granted collateral estoppel effect to determinations of "law," absent "injustice," so long as "both causes of action arose out of the same subject matter or transaction."186 This meant, for example, that a determination of the "legal sufficiency or the construction" of a contract was binding in a later action for a subsequent breach of the same contract, that a determi-

182 See L. Jaffe, Judicial Control of Administrative Action 546-59 (1965).

183 See, e.g., Sioux City \& P.R.R. v. Stout, 84 U.S. (17 Wall.) 657, $663-65$ (1873).

$18 t$ Restatement of Judgments $\$ 70$, Comment $b$ (1942).

${ }_{185}$ Id. $\$ 68$, Comment p \& Illustration 14. See The Evergreens v. Nunan, 141 F.2d 927, 929-31 (2d Cir. 1944).

iss Id. $\$ 70$. 
nation that an employee qualified for a pension was binding in an action for a later installment under the same statute, and that a decision that one corporate note was ultra vires was determinative in an action on another identical note issued at the same time. ${ }^{187} \mathrm{On}$ the other hand, under this test a decision that written promises require no consideration would not be binding in an action on "another written promise," nor would a decision that unlicensed drivers are not exonerated by contributory negligence be conclusive in an action on "another collision." 188

In Huffman and Lektro-Vend, where the same conduct was in issue in both state and federal court, it seems clear that there was only one "subject matter or transaction." In Sosna and in Wooley, on the other hand, the conduct in both suits was recurrent though identical, and the federal actions sought prospective relief only. Yet in terms of res judicata policy, I cannot distinguish Sosna or Wooley from the Restatement's examples in which preclusion was said to be proper. If a decision that one is eligible for a pension today determines his eligibility tomorrow, as the Supreme Court ${ }^{189}$ as well as the Restatement has held, the same should be true of a decision that one is ineligible for a divorce or has no right to deface his license plates.

The revised Restatement is phrased so as to suggest a reduced importance to the law-fact distinction. ${ }^{190}$ Preclusion will not occur on an issue of law "if the two actions involve claims that are substantially unrelated," if there has been "an intervening change in the applicable legal context," or if it would result in "inequitable administration of the laws." 191

187 Id. \$ 70, Comment b.

${ }_{189}$ Id. $\$ 70$, Comment d.

${ }_{189}$ United States v. Moser, 266 U.S. 236 (1924). Two Supreme Court tax decisions draw a fine distinction in this respect. Tait v. Western Md. Ry., 289 U.S. 620 (1933), held a decision against deductibility of amortized bond discount binding in a later tax year with respect to the same bonds: Though each year's tax was a separate cause of action, nothing in the "annual nature of the exaction" was meant to deprive parties of "relief from redundant litigation of the identical question of the statute's application to the taxpayer's status." Id. at 624. But in Commisioner v. Sunnen, 333 U.S. 591 (1948), a decision as to the taxability of payments under one contract was held not binding as to later payments under a separate though identical agreement: "For income tax purposes, what is decided as to one contract is not conclusive as to any other contract which is not in issue, however similar or identical it might be." Id. at 602. Tait was distinguished as a case in which "the two proceedings involved the same instruments." Id. at 602.

I find this distinction too subtle to bear any relevance to res judicata policy and prefer the earlier Tait decision. But Sunnen said nothing to impair the authority of the pension decision in United States v. Moser, 266 U.S. 236 (1924), which is most directly in point.

190 The general rule is that collateral estoppel applies to "an issue of fact or law." Restatement (Second) of Judgments $\$ 68$ (Tent. Draft No. 1, 1973).

${ }^{191} I d . \$ 68.1(\mathrm{~b})$. An example given again suggests that the state and federal suits in 
No "change in the applicable legal context," was suggested in any of our cases. There remains the question, under both Restatements, whether preclusion would result in "injustice" or in "inequitable administration of the laws." Two examples given in both Restatements are taken from Supreme Court decisions in which determinations of taxability were held not binding in litigation over later taxes on the same or similar transactions. ${ }^{192}$ In both cases the Court was concerned that to hold one taxpayer's liability forever concluded by a single determination could result in unequal treatment of persons similarly situated. ${ }^{193}$

This is a legitimate concern, and it is present in Wooley. Res judicata could keep one person alone from obscuring his plates if someone else obtained a later decision that the law was unconstitutional. But it was not the unadorned possibility of unequal treatment that led the Court to deny preclusive effect in the two cases cited by the Restatements. In the first case, the Court relied heavily on a rule of the Court of Customs Appeals, whose practice the Court thought entitled to considerable respect, almost as though it were a state court. ${ }^{194}$ In the second, the Court went some length to show that there had been a "change or development in the controlling legal principles" since the initial decision. ${ }^{195}$ The theoretical possibility of future unequal treatment was also present in the pension case noted above. Yet the Supreme Court held the prior determination conclusive.

The risk of unequal treatment must be balanced against the policy interests̀ served by preventing repeated or split litigation. One commentator has argued that res judicata was correctly rejected in Wooley by analogy to successive prosecutions: "of course" a decision against the criminal defendant would not be conclusive

Sosna, Huffman, Wooley, and Lektro-Vend would not be considered as "substantially unrelated": A decision that a trademark is invalid is binding in a second action for a later infringement of the same mark. Id. \$68.1, Illustration 1 .

112 Commissioner v. Sunnen, 333 U.S. 591 (1948) (income tax on royalties from same contract in successive years); United States v. Stone \& Downer Co., 274 U.S. 225 (1927) (customs classification of successive wool shipments). See RESTATEMENT OF JUDGMENTS § 70, Comment f (1942); Restatement (Second) of JudGments $\$$ 68.1, Reporter's Note at 185 (Tent. Draft No. 1, 1973).

${ }^{193}$ See Commissioner v. Sunnen, 333 U.S. 591, 599 (1948) ("tax treatment different from that given to other taxpayers of the same class"); United States v. Stone \& Downer Co., 274 U.S. 225, 236 (1927) (competitive advantage or disadvantage).

iw United States v. Stone \& Downer Co., 274 U.S. 225, 237 (1927). While the Court added that the practice was "wise," in a later case giving effect to a prior determination of tax status, the Court distinguished Stone \& Downer as based on Court of Customs Appeals practice and on the "unique character" of the question there presented. Tait v. Western Md. Ry., 289 U.S. 620, 625 (1933).

iss Commissioner v. Sunnen, 333 U.S. 591, 602-07 (1948). 
on the constitutional issue in a later prosecution against him ${ }^{186}$ for violating the license plate law. ${ }^{197}$ Although no authority is cited for this conclusion, ${ }^{198}$ I do not doubt many courts would agree with it. Yet it seems clear that if the parties were reversed the opposite result would follow: a declaratory judgment that the license plate law was unconstitutional would generally bar later prosecutions under that law. ${ }^{199}$ I would resolve the inconsistency by extending the preclusive effect of declaratory judgments to successive prosecutions. Absent a change in law or other extraordinary circumstance, one decision per violator is enough. ${ }^{200}$

Wooley differs from the declaratory judgment case in that there was no decision on the constitutional issue in the state prosecutions. This distinction means that unequal treatment could occur in a case

${ }_{196}$ Others with a cognizable interest in attacking the license plate law's constitutionality could not have their rights concluded without being given an opportunity to litigate the issue. This is a matter of due process, U.S. Const. amend. XIV, $\S 1$. See, e.g., Blonder-Tongue Laboratories, Inc. v. University of Ill. Foundation, 402 U.S. 313, 329 (1971); Zenith Radio Corp. v. Hazeltine Research, Inc., 395 U.S. 100, 110 (1969). The catchall exception to this due process principle concerns persons who are in "privity" with a party to the judgment. See Griffin v. McCormick, No. 77-1250 (1st Cir. filed Jan. 19, 1978), slip op. at 12-14; F. JAMES \& G. HAZARD, supra note 57, at 584-600.

${ }^{197}$ Developments, supra note 47 , at 1345 .

198 The basis for the assertion seems to be the dictum of the Restatement (SECOND) of JUDGMENTS $\$ 68.1(b)$, Reporter's Notes at 185 (Tent. Draft No. 1, 1973), that issues of law may be relitigated in subsequent suits involving different transactions. Developments, supra note 47 , at $1345 \mathrm{n} .68$.

199 The Supreme Court treated this as an open question in Steffel v. Thompson, 415 U.S. 452 (1974): "[T] point is not free from difficulty and the governing rules remain to be developed with a view to the proper workings of a federal system." Id. at 470-71 (quoting Perez v. Ledesma, 401 U.S. 82, 125 (1971) (opinion of Brennan, J.)). Mr. Justice Rehnquist in a concurring opinion seemed to think there was real doubt: "A declaratory judgment is simply a statement of rights, not a binding order supplemented by continuing sanctions . . . . [T] he federal plaintiff . . . may, of course, raise the federal declaratory judgment in the state court for whatever value it may prove to have." Id. at 482 (footnote omitted). There should, however, be no doubt:

The Declaratory Judgment Act itself provides that a "declaration shall have the force and effect of a final judgment or decree," 28 U.S.C. § 2201; eminent authority anticipated that declaratory judgments would be res judicata, E. Borchard, Declaratory Judgments $10-11$ ( $2 \mathrm{~d}$ ed. 1941); and there is every reason for not reducing declaratory judgments to mere advisory opinions.

Id. at 477 (White, J., concurring). "Every reason" includes the case-or-controversy limitation of article III. See also Developments, supra note 70, at 1357; RESTATEMENT (SECOND) of JudGMenTs $\$ 76$ (Tent. Draft No. 1, 1973).

${ }^{200}$ It has been suggested that precluding a defendant in a criminal prosecution from relitigating issues decided adversely to him in a prior prosecution might conflict with his constitutional rights-specifically, his right to trial by jury and his right to confront witnesses. R. CASAd, Res Judicata IN a Nutshell 252-53 (1976). Whatever force this argument has with respect to issues of fact is absent with respect to questions of law such as the constitutionality of the license plate law in Wooley. 
like Wooley without a change in law, but it also makes the equities less favorable to new litigation than when the law has changed, for in Wooley any inequality would be brought about by a party's unjustified failure to raise the issue in the first litigation. I suspect the chance that New Hampshire would continue to go after a single violator after its law has been authoritatively invalidated as to everyone else is purely mythical. If it should happen, there would be a strong case for relief from res judicata under the inequality exception, but we should wait for the problem to arise.

8. Exclusive Federal Jurisdiction. The federal action in Lektro-Vend was based on the Sherman Act, and over such claims federal courts have exclusive jurisdiction. ${ }^{201}$ If the state court had no power to consider his antitrust defense, a litigant could not be barred by failure to assert it there. But statutes giving federal courts exclusive jurisdiction of antitrust or patent claims do not deprive state courts of the power to decide antitrust or patent issues raised in defense. ${ }^{202}$ Nevertheless, a Second Circuit opinion by Judge Learned Hand ruled that to give res judicata effect to a state decision on an antitrust defense would undermine the exclusivity of federal jurisdiction in an action seeking affirmative relief. ${ }^{203}$

This argument is not without force, especially when, as in Lektro-Vend, the state court defendant has chosen not to litigate the federal defense in state court. Nevertheless I do not find it compelling. The basic inconsistency is between the statute making jurisdiction over antitrust claims exclusively federal and the decision that state courts may decide antitrust defenses. This decision seems to imply that the state court decision will have some consequence, for relitigation of decided issues is certainly not the usual course. Judge Hand's position, moreover, seems irreconcilable with the Supreme Court's flat statement, in refusing to enjoin a state court action seeking to compel assignment of a patent, that a state judgment establishing facts that proved the patent's invalidity would be entitled to collateral estoppel effect in a federal infringement suit. ${ }^{204}$

2015 U.S.C. $\$ 15$ (1970).

${ }^{202}$ Platt v. Paris Gas Light \& Coke Co., 168 U.S. 255, 259 (1897) (patents).

${ }^{203}$ Lyons v. Westinghouse Elec. Corp., 222 F.2d 184 (2d Cir.), cert. denied, 350 U.S. 825 (1955). See Note, Res Judicata: Exclusive Federal Jurisdiction and the Effect of Prior State Court Determinations, 53 VA. L. REv. 1360, 1367 (1967), basically approving Lyons. The preponderance of modern decisions reject the Lyons holding. See, e.g., Granader v. Public Bank, 417 F.2d 75, 81 (6th Cir. 1969), cert. denied, 397 U.S. 1065 (1970); Vanderveer v. Erie Malleable Iron Co., 238 F.2d 510, 512-13 (3d Cir. 1956), cert. denied, 353 U.S. 937 (1957).

${ }_{204}$ Becher v. Contoure Laboratories, Inc., 279 U.S. 388, 391-92 (1929) (Holmes, J.). Judge Hand's attempt to distinguish Becher on the ground it gave effect only to fact findings instead 
It should be held that the exclusive jurisdiction provision of the Sherman Act does not deprive state court judgments of res judicata effect as to defenses of which they have jurisdiction.

9. Courts of Limited Jurisdiction. The federal plaintiff in Wooley v. Maynard had been convicted in the Lebanon District Court, whose criminal jurisdiction is limited to offenses carrying penalties of not more than $\$ 1000$ or one year in jail. ${ }^{205}$ To give collateral estoppel effect to decisions of such courts in later actions on claims exceeding their jurisdictional limitations would undermine those limitations, ${ }^{206}$ though some courts have done it. ${ }^{207}$ No such problem is presented in Wooley, however, because any future license plate violations would fall within the district court's jurisdiction.

But there is a more fundamental question. The Supreme Court of California, conceding that the judgment of any inferior court is res judicata as to the cause of action adjudicated, has held collateral estoppel wholly inapplicable to determinations by small-claims courts:

[T] he small-claims court functions informally and expeditiously ... . [T] here are no attorneys, no pleadings and no legal rules of evidence, there are no juries, and no formal findings are made . . . . [O]nly the defendant may appeal . . . . [W]e may reasonably assume that . . . the technical aspects of proximate cause, contributory negligence, imputed negligence and the doctrine of last clear chance, of necessity have not been fully presented or considered. ${ }^{208}$

I agree it would contravene the purpose of an informal tribunal such as the California small-claims court to make its determinations binding as to future conduct not directly in issue. But the court was careful to point out that it was not speaking of all courts of limited jurisdiction; it indicated that collateral estoppel effect should be given to the decisions of 'inferior courts such as justices' and municipal tribunals, where such courts, though of lesser jurisdiction, nevertheless function as courts of law with some form of

of barring the remedy outright is unpersuasive in light of the competing arguments cited in the text. See also 8 Stan. L. Rev. 439, 443-46 (1956).

${ }^{205}$ N.H. REv. Stat. ANN. \$ 502-A:11 (1968).

208 See Restatement of Judgmenrs \$ 58, Comment e (1942); Annot., 147 A.L.R 196, 21932 (1943).

${ }^{207}$ See, e.g., Todhunter v. Smith, 219 Cal. 690, 28 P.2d 916 (1934); Fireman's Fund Ins. Co. v. Bybee, 322 S.W.2d 657 (Tex. Civ. App. 1959).

2os Sanderson v. Niemann, 17 Cal. 2d 563, 573-74, 110 P.2d 1025, 1030-31 (1941). See also Legislation Note, 34 CoLum. L. REv. 932, 942 n.76 (1934), quoting a New York statute explicitly so providing. 
pleadings, and in accordance with legal rules of evidence and the right of representation by counsel."20s

The New Hampshire district courts do not appear to be of such an informal character as to deprive their judgments of collateral estoppel effect. They are described as "courts of record." 210 The state supreme court and a committee of judges are authorized to adopt procedural rules for them..$^{211}$ While the judge in a New Hampshire district court need not be a lawyer, ${ }^{212}$ the statute provides that the defendant in such a court may appeal a criminal conviction ${ }^{213}$ and that questions of law may be referred to the state supreme court..14 The state supreme court has described the district courts as courts of "special and limited jurisdiction" and has held their "inherent powers" are not so great as those of the general courts, ${ }^{215}$ but it has not had occasion to decide the question whether their decisions are due collateral estoppel effect. In the absence of evidence that the procedures of the court were such as to make it impracticable or undesirable to litigate the constitutional question there, the judgments of the state tribunal in Wooley should be respected and given collateral estoppel effect.

\section{CoNCLUSION}

The number of possible objections to the application of res judicata in the four cases I have discussed is intimidating. Some, while they may survive in certain states, are wholly unpersuasivesuch as mutuality and the criminal nature of the state proceeding. The fashionable conclusion that section 1983 cases are exceptional for res judicata purposes is a product of wishful thinking. Up to this point, I would expect most informed people to agree.

I encounter rough weather when I argue that a state court's constitutional decision should be binding as to later prosecutions for similar actions by the same party, despite the danger of unequal treatment. When I argue for the same result although the constitutional issue was not litigated or decided in state court, I push res

17 Cal. 2 d at 574-75, 110 P.2d at 1031. Freeman's treatise did not even recognize a problem: "The final judgments of courts or tribunals not of record, such as justices of the peace, are as conclusive as those of courts of record, both as a merger or bar and as an estoppel as to any particular matter of fact adjudicated." 2 A. FREEMAN, supra note 121 , at $\S 634$.

210 N.H. Rev. Stat. ANN. \$ 502-A:20 (1968).

211 Id. \$ 502-A:18, 19-a.

212 Id. \$ 502-A:3.

213 Id. \$ 502-A: 12 .

211 N.H. Rev. Stat. Ann. \& 502-A:17a (1968\&\& 1975 Supp.).

215 State v. Flynn, 110 N.H. 451, 453, 272 A.2d 591, 593 (1970). 
judicata beyond where I can say any court has intentionally gone. I would not be at all surprised if many of you have left the ship.

My aim is not to convince you specifically that Wooley should have been barred by res judicata. Given section 1738's reference to state law, I think it unlikely that were I a federal judge I would have so held. ${ }^{216} \mathrm{I}$ am not even sure I would have done so if I felt free to fashion the ideal law of res judicata. Perhaps loss of a constitutional right to take future action is after all too high a price to pay for lack of skill in presenting one's case, especially when one has no lawyer. Perhaps too I have been unfair in examining the applicability of the exceptions to res judicata on the basis of the facts of each case while relying upon the costs of multiple litigation in cases generally. On the facts of Wooley it is not clear that the costs of omitting to challenge the law earlier were substantial. Furthermore, the cost and uncertainty of making case-by-case inquiries into competing considerations may justify categorical exceptions that are in some respects overinclusive.

One need not agree with every step of my extreme argument in order to share my concern that the propriety of affording a second opportunity for litigation should have been a central concern in the four cases. The law of res judicata is directly concerned with that problem. Its application should therefore have been seriously considered.

I suggest to attorneys that res judicata generally be raised as a defense when a party defeated in state court seeks to obtain a second round in federal. I urge state courts to rethink archaic limitations on res judicata that permit unjustifiable duplication or splitting of litigation. And I ask federal courts to take care, when the defense is properly raised, to respect the command of Congress in section 1738.

${ }_{215}$ See, e.g., Lovejoy v. Ashworth, 94 N.H. 8, 10, 45 A.2d 218, 219 (1946) (dictum), stating that in a subsequent proceeding on a different cause of action a judgment was determinative only as to matters actually decided; Bottomly v. Parmenter, 85 N.H. 322, 326, 159 A. 302 , 304 (1932) (holding an action to recover for services quantum meruit not barred by a decision against recovery for the same services on contract because the claims are essentially different). 